\title{
Towards a better understanding of fashion clothing involvement
}

\begin{abstract}
This study is concerned with consumer involvement in fashion clothing. Amidst the consumer objects that facilitate everyday life, fashion clothing is an important and meaningful object for many consumers. In the extant consumer literature few studies have attempted to examine fashion clothing involvement, particularly in terms of its causes and outcomes. This study then focuses on building a reliable nomological network to bring a greater understanding to this facet of consumer behaviour. To achieve this, materialism and gender are examined as drivers of fashion clothing involvement. Recreational shopper identity, ongoing information search, market mavenism, and purchase decision involvement are explored as outcomes of fashion clothing involvement. Data were gathered using an Australian Generation Y sample resulting in 200 completed questionnaires. The results support the study's model and its hypotheses and show that materialism and gender are significant drivers of fashion clothing involvement. While also, recreational shopper identity, ongoing information search, market mavenism and purchase decision involvement are significant outcomes of fashion clothing involvement.
\end{abstract}

Keywords Fashion clothing involvement, Recreational shopper identity 


\section{Introduction}

Over the past few decades, studies of involvement have grown in number and importance as a consequence of increasing focus on consumer studies. Along with Western developments in industrial production and the proliferation of material goods, fashion clothing is now recognised as an important part of our human, corporeal existence. For example, fashion clothing is unique in its material proclivities and its relation to our body; we experience life through clothing items (Woodward, 2007). This paper is concerned with involvement consumers have with fashion clothing as a product category. In doing this, we seek to highlight the effect that fashion clothing involvement has on various consumer behaviour variables.

The term 'fashion' is accounted for through the attributes of change, ambivalence, novelty and added value when associated with an object (Kawamura 2005, pp. 4-5). It follows then that a continued focus on this ever-changing consumer object would be of great benefit to consumption studies. Using the arguments of Eicher and Roach-Higgins (1992, p. 13), the inclusion of the term fashion clothing in this research refers to all items that adorn any part of the body. Defining fashion clothing in this manner allows for a more thorough account of fashion clothing yet avoids potential bias to certain items within the category, like jewellery for example.

In conceptualising a nomological network, this study proposes that materialism and gender are important drivers of fashion clothing involvement (FCI). Furthermore, it is posited that recreational shopper identity (RSI), market mavenism, ongoing information search (OIS) and purchase decision involvement (PDI) are outcomes of FCI. The present research extends the scope of the existing nomological FCI network developed by O'Cass (2004). For instance, 
whilst he found that decision confidence and subjective knowledge are FCI outcomes, this study is the first to conceptualise RSI as an FCI outcome. This paper is also one of the only studies to conceptualise market mavenism as an outcome of FCI. The proposed theoretical model is examined in the context of Australian Generation Y (Gen Y) consumers.

Australian Gen Y consumers are an important and appropriate context for the study of FCI. Here, Daniels' (2007, p. 6) definition of Gen Y is adopted and accounts for those persons born between 1977 and 1994 inclusively. Many consumer studies focus on Gen Y consumers from America (e.g. Bakewell and Mitchell, 2003; O’Donnell, 2006; Sullivan and Heitmeyer, 2008; Wolburg and Pokrywcyniski, 2001) or Asia (e.g. Arora, 2005; O'Cass and Choy, 2008; O'Cass and Lim, 2002). However, as noted by Solomon (2004), the distinguishing characteristics of individuals that comprise an age cohort differ across cultures. Thus, the findings of these studies may not necessarily be generalisable to an Australian context. For fashion marketers, in an industry that is worth billions worldwide (Australian Bureau of Statistics, 2009), understanding young consumers is important as they are predicted to become the most significant retail spending group in Australia by the year 2015 (Daniels, 2007; Huntley, 2006).

This paper begins with a review of the extant FCI literature and develops the proposed conceptual model, 'Fashion Clothing Involvement Drivers and Outcomes' with six hypotheses. This is followed by an outline of the research design used in the study including data collection methods. The paper then presents the analysis and results of the study and concludes with a discussion of the study's findings, its limitations and recommended areas for future research. 


\subsection{Fashion Clothing Involvement}

Since being introduced by Krugman (1965) and McLuhan (1964) nearly 50 years ago, consumer involvement has developed into an important area of consumer research explaining many aspects of decision making and consumption (e.g. Evrard and Aurier, 1996; Flynn and Goldsmith, 1993; Kim, 2005; Michaelidou and Dibb, 2006; Mittal and Lee, 1989). As a more specific thread in the involvement literature, FCI is a growing research stream associated with how important, meaningful and relevant fashion clothing is to the lives of consumers. It is a research stream dedicated to explaining fashion clothing related consumption behaviours (e.g. Auty and Elliot, 1998; Bloch et al., 2009; O'Cass, 2000, 2004).

While some consumers find the fashion clothing items they buy and wear to be involving, this is not the case for all. As such, FCI represents an individual difference variable which, according to O'Cass (2004, p. 878), follows “a continuum from total attachment (or absorption) in fashion clothing and related activities (very high involvement) to complete detachment or automaticity (very low involvement)". In this respect, the more fashion clothing occupies a key position in a consumer's life, the greater the FCI experienced. Given this, FCI is defined in this study as "the extent to which a consumer views the related fashion [clothing] activities as a central part of their life" (O'Cass, 2004, p. 870). Petty and Cacioppo's (1984) Elaboration Likelihood Model of persuasion (ELM), which was developed to understand how attitudes are formed and change, highlights how consumer decision making changes under differing levels of involvement. The ELM suggests there are clear differences in decision making between those who are high in involvement and those who are low in involvement. This implies in terms of fashion clothing, that highly involved consumers use a central route to their fashion clothing decision making, as they are motivated by and find fashion clothing personally relevant. Alternatively, less involved consumers tend 
to follow a more peripheral, surface route to their fashion clothing decision making (Josiassen, 2010; Petty and Cacioppo, 1980).

While recent work has expanded our understanding of FCI (eg: O'Cass, 2004), the literature fails to provide a comprehensive picture of the conditions that foster involvement in this lucrative product category, and of its outcomes. Given the current poor retail climate within Australia, there are perhaps fewer areas of greater importance to both retailers and marketing academics. As such, findings from O'Cass (2004) are used to frame this study. By examining FCI in the context of an extended nomological network as advocated by O'Cass (2004), we can better understand how consumer involvement in fashion clothing is formed and where this leads consumers in their decision-making processes.

\subsection{Drivers of Fashion Clothing Involvement}

\subsubsection{Materialism}

In seeking to better understand the relationship between consumers and fashion clothing, it is important to understand how consumer values influence this relationship. Materialistic values influence the need for goods in terms of identity search, self-presentation, aesthetic consumption and for the marking of special occasions (O'Shaughnessy and O'Shaughnessy, 2007). Defined by Belk (1984, p. 291) as "the importance a consumer attaches to worldly possessions", materialism explains differences across consumers in well being related to possession ownership (Burroughs and Rindfleisch, 2002), impressions of others through publicly consumed goods (Belk, 1995), attachment to material possessions (Richins, 1987), material possessions as communication devices (Douglas and Isherwood, 1996) and selfconcept/image management (Wang and Wallendorf, 2006). 
Materialism is rooted in Belk's (1988) theory of the Extended Self, which explains how possessions can become a part of our notion of self and personal identity. At its highest levels, materialists value possessions so greatly that they are thought to assume a central place in life, providing life's greatest source of satisfaction and dissatisfaction (Browne and Kaldenberg, 1997; Fournier and Richins, 1991; Richins and Dawson, 1990). Materialists rely heavily on possessions to symbolise individual qualities, reference and membership group affiliations and social standing within the wider community (Dittmar, 1992; Richins, 1994). Overall, collective findings imply that materialism plays an important role in the development of consumers' relationships with particular objects (O'Cass, 2004).

Importantly, materialism is often portrayed in the literature as a negative personality trait (i.e. Burroughs and Rindfleisch, 2002; Fournier and Richins, 1991; Kasser, 2002; O'Shaughnessy and O'Shaughnessy, 2007; Richins, 1994; Richins and Dawson, 1992) and is connected to notions of possessiveness and envy. Materialism has even been referred to by Kasser, (2002, p. xii) as "the tragic tale of modernity - we are the snakes eating our own tails". Despite this view, O'Shaughnessy and O'Shaughnessy $(2007$, p. 14) argue that materialism is not solely a narcissistic trait resultant of modern times, but instead "covers a spectrum of human behaviour [where] materialism simply becomes part of our humanity". Furthermore, O'Cass (2001) argues materialism may be a necessary underlying value for consumers to possess in order to become highly involved in goods like fashion clothing. In his study, O'Cass (2004) found empirical evidence for this proposition. Certainly, when considering the ELM, it would be expected that fashion clothing messages sent through the central route would be well received by materialists, who are argued here to find the information personally important and relevant. Thus, it is hypothesised:

H1: Materialism will be significantly and positively related to FCI. 


\subsubsection{Gender}

Another variable that can potentially explain differences in consumer attachments to possessions and marketplace behaviours is gender (Auty and Elliot, 1998; Browne and Kaldenberg, 1997; Dittmar, 1992; O’Cass, 2000, 2004). Gender is a social construct defined by Gentry et al. (2003, p. 3) as “...the symbolic role definition attributed to members of a sex on the basis of historically constructed interpretations of the nature, disposition and role of members of that sex" and has been found to influence FCI (Auty and Elliot, 1998; O'Cass, 2000, 2004; Tigert et al., 1980).

Gender role socialisation helps to account for variances in behaviours between males and females. Socialisation is "the process by which an individual learns the norms and values of the group and society" (Assael et al., 2007, p. 336). Underpinned by social learning theories, in gender role socialisation, an individual learns their gender identity from others of the same sex by early adulthood. It is this gendered identity that forms the basis of an individual's personality and belief system (Chodorow, 1978; Gilligan, 1987). For instance, Ganesan-Lim et al. (2008) note significant differences between behaviours that are expected of girls and boys in the pursuit of being feminine and masculine. This also extends to the relationship that men and women typically have with fashion clothing. For instance, the extant fashion clothing literature highlights that females in general are more fashion conscious than men (Solomon and Schopler, 1982), more interested in fashion, more attuned to fashion and more willing to try new styles (Davis, 1994). Also, in his study, O'Cass (2004) found that females indicated higher levels of FCI than males. While it is acknowledged that society's expectations of gender roles are slowly changing (Gentry et al., 2003; Kaiser, 1998), today’s marketplace continues to perpetuate the relationship between female consumers and fashion clothing (Sassatelli, 2007). For instance, consumers are bombarded by images of youthful, 
female beauty in the media and women are judged by this standard in Western culture. Thus, it is hypothesised:

H2: Gender (f) will be significantly and positively related to FCI.

\subsection{Outcomes of Fashion Clothing Involvement}

\subsubsection{Recreational Shopper Identity}

Shopping is an enjoyable, experiential activity for many consumers and is now considered as a form of recreation in of itself (Falk and Campbell, 1997). According to Prus and Dawson (1991, p. 160), recreational shopping can act as a means for "acknowledging, entertaining or expressing one's self". Recreational shopper identity (RSI) is a relatively new construct in the consumer research literature. Theoretically, RSI is grounded in Bellenger and Korgaonkar's (1980) seminal work concerning the "recreational shopper" (see Lunt and Livingston, 1992; Prus and Dawson, 1991; Stone, 1954; Westbrook and Black, 1985) and also the leisure identity literature (see Haggard and Williams, 1992; Shamir, 1992). RSI is defined as “ $a$ dimension of an individual's self-concept whereby a consumer defines himself or herself in terms of shopping for recreational or leisure purposes" (Guiry et al., 2006, p. 75). RSI is a construct that encompasses the psycho-social practices of the modern consumer where RSI has been found to affect marketplace behaviours in relation to shopping pursuits and heightened levels of leisure experience (Guiry et al., 2006). Thus, through the introjection (internalisation) of leisure shopping practices, the consumer is able to construct and confirm elements of their self-identity where the self is in a constant state of becoming.

Theoretically, it has long been established that high involvement can influence the incorporation of a product or activity into an individuals' self-concept (Belk, 1988; Bloch, 1986; Fischer and Gainer, 1991; Shamir, 1992). As such, it seems likely that RSI and 
involvement are linked. Guiry and Lutz (2000) relate the act of recreational shopping to the person-object relationship that is also identified in the consumer involvement literature, while Evrard and Aurier (1996) suggest that the person-object relationship may be stronger in recreational shoppers. Of relevance here, in developing their RSI measure, whilst Guiry et al. (2006) imply that consumer involvement is an underlying variable affecting RSI behaviours, they neither hypothesised nor empirically examined this relationship. Thus, while theoretically conceptualised, no study has empirically explored the relationship between consumer involvement and RSI. In this paper then, it is argued that consumers who are highly involved in fashion clothing will view recreational shopping as part of their identity. Thus, it is hypothesised:

H3: FCI will be significantly and positively related to RSI.

\subsubsection{Ongoing Information Search}

While much research has focused on either internal (information retrieved from ones memory) or external search (effort directed to obtaining information related to a specific purchase) (i.e. Beatty and Smith, 1987; Bettman, 1979; Schmidt and Spreng, 1996), this study is concerned with ongoing information search (OIS). OIS is defined as "search activities that are independent of specific purchase needs or decisions" (Bloch et al., 1986, p. 120) and can include activities such as reading a fashion magazine or browsing an online fashion boutique. As argued by Bloch et al (1986), consumer motivation to engage in OIS is grounded from either the need to information-bank, thus increasing product expertise that may add to feelings of self actualisation and improving the quality of future product selections, or, the need to have fun and experience positive affect. In other words, OIS can represent a leisure activity performed for its own sake, with no goals or outcomes other than the pleasure of the information search. Thus, for this study, OIS reflects continuing interest or enthusiasm with 
fashion clothing and does not occur in order to solve a recognised problem. Rather, OIS is a means of maintaining general fashion awareness.

In terms of fashion clothing, empirical evidence shows a consumer's propensity to engage in OIS may be determined to some extent by high involvement (Bloch et al., 1986). To assess OIS in the 1980s, Bloch et al. (1986) developed an OIS scale that included items that focused on traditional information sources such as interpersonal communication, stores, catalogues and magazines. The introduction and proliferation of the Internet and decline in readership of traditional mediums like store catalogues and newspapers, means that the evidence presented by Bloch et al. (1986) is outdated and deficient for understanding patterns of information search as they occur today. The use of the Internet has induced extensive changes to the methods and frequency by which consumers access product related information. Thus, if consumers are interested in the product category, there have never been more opportunities to be up-to-date with seasonal changes, current styles and trends of clothing considered fashionable. Using these arguments then, highly involved fashion clothing consumers are likely to engage in a broad range of OIS activities. Thus, it is hypothesised:

H4: FCI will be significantly and positively related to OIS.

\subsubsection{Market Mavenism}

Understanding what motivates consumers drives much consumer research, particularly influential consumers (e.g. Goldsmith et al., 1999; O’Cass, 2000) like market mavens (Clark and Goldsmith, 2005). Market mavens are defined as "individuals who have information about many kinds of products, places to shop and other facets of markets, and initiate discussions with consumers and respond to requests from consumers for market information" (Feick and Price, 1987, p. 85). They are an attractive target segment (Goldsmith et al., 2006) 
as their marketplace expertise leads to early awareness and possibly, early adoption of new products (Feick and Price, 1987; Williams and Slama, 1995).

In a study by Clark and Goldsmith (2005), susceptibility to normative interpersonal influence, global self-esteem and consumer need for uniqueness were found to be market maven antecedents. Apart from their study however, little empirical attention has been paid to the drivers of market mavenism within the consumer research literature (for exceptions see: Goldsmith et al., 2006; Stokburger-Sauer and Hoyer, 2009). As such, gaining a greater understanding of mavenism is important for theoretical purposes (Goldsmith et al., 2006) and also to provide fashion clothing marketers and retailers with the tools to reach this important and influential consumer type.

As market mavens are described as consumers who are highly involved in the marketplace on a continual basis and are interested in product-related information (Smith and Bristor, 1994), it seems likely that product involvement that may be a motivating force behind mavenism. Recently, empirical evidence from Germany by Stokburger-Sauer and Hoyer (2009) found a link between involvement (clothing) and market mavenism. While this is an important finding, further research needs to establish the external validity of this relationship (Stokburger-Sauer and Hoyer, 2009). That fashion clothing is an important, relevant part of everyday life means a highly involved consumer is more likely to display and be capable of displaying market maven characteristics like sharing product, brand and store information with others for different fashion clothing products. Thus, it is hypothesised:

H5: FCI will be significantly and positively related to market mavenism. 


\subsubsection{Purchase Decision Involvement}

Within the extant literature, involvement (product category) has been shown to lead to greater involvement in the purchase decision itself, for a product within that category. Purchase decision involvement (PDI) is defined as "the degree a consumer is involved in the purchase decision" (O'Cass, 2000, p. 558) and is argued by Mittal (1989) as the most important form of involvement for marketers, particularly at the brand level. Attention in PDI research has focused on understanding PDI and in terms of product importance, product involvement, in durable and in non-durable products (Browne and Kaldenberg, 1997; Mittal, 1989; Mittal and Lee, 1989; Muehling, Laczinak and Andrews, 1993; O’Cass, 2000; Smith and Bristor, 1994). Importantly, PDI has been found to be greatly relevant to fashion clothing (O'Cass and Choy, 2008).

Using the ELM model, in high involvement purchase decisions, decision-making processes proceed through the central route, where consumers evaluate many brands and product attributes prior to making a final purchase decision (Petty, and Cacioppo; 1984; Browne and Kaldenberg, 1997). These processes highlight the connection between conceptualisations of high FCI and high PDI. For instance, in this paper it is argued that a consumer who is highly involved in fashion clothing will spend more time with this product category and be more involved in the processes associated with making purchase decisions about fashion clothing. Thus, it is hypothesised:

H6: FCI will be significantly and positively related to PDI.

\section{Methodology}

A questionnaire was developed to tap the focal constructs of the study. First, items were pooled from the extant marketing and consumer behaviour literatures. These items were then 
presented to a focus group for clarification of understanding of terms and to strengthen the quality of the instrument. Measures used in the final questionnaire included 13 items from Richins and Dawson's (1992) materialism scale, which was reported to be highly reliable $(\alpha=0.87)$. An example of an item from the scale is "I try to keep my life simple, as far as possessions are concerned". FCI was measured via eight items from the reportedly highly reliable $(\alpha=0.98)$ scale by O'Cass (2000). An example item is "Fashion clothing means a lot to me". The 5-item RSI scale developed by Guiry et al. (2006) was adopted as it is the only self-report measure in the literature. Guiry et al. (2006) reported the scale as highly reliable (in two studies $\alpha=0.83$ and $\alpha=0.90$ ) and an example of an item is "Shopping is important for my self-definition". The 5-item market maven scale by Feick and Price (1987) was adopted in this study. Feick and Price (1987) reported the scale as highly reliable $(\alpha=$ 0.82 ) and an example item is "I like introducing new brands and products to my friends". The 10-item PDI scale by O'Cass (2000) was adopted as O'Cass (2000) reported the scale to be highly reliable $(\alpha=0.95)$. An example item is "Making purchase decisions for fashion clothing is significant to me". Four items were developed from a focus group to represent an OIS index and included information search via friends and the Internet. All scales used seven-point Likert-type scales with poles that ranged from 1-Strongly Agree to 7-Strongly Disagree, except for the OIS measure. A 7-point frequency of use scale was used to measure OIS behaviours. An example item is "When looking for information about fashion clothing, I use the clothing stores".

The questionnaire was then pilot tested on a student sample $(n=40)$ to examine its psychometric properties via data reduction, exploratory factor analysis (EFA) and reliability tests (Cronbach's alpha). All items factored according to the literature and displayed internal consistency, with the exception of two items from Richins and Dawson's (1992) materialism 
scale. This resulted in word simplification across the relevant items. The final questionnaire was then administered to a sample of undergraduate university students at a large Australian University. Overall, this data collection process resulted in 200 completed and usable questionnaires.

\section{Results}

\subsection{Preliminary Results}

As recommended by Hulland (1999) and d'Astous (2000), the data were qualified for use in the main study. This was achieved via a number of preliminary analysis techniques including exploration of sample profiles, EFA, reliability testing (Cronbach's alpha) and validity testing (convergent and discriminant).

The sample profile for the main study consisted of 200 participants with a gender distribution of $43.5 \%$ males and $65.5 \%$ females. Respondents reported that their ages ranged from 17 to 32 years, with a mean age of 21 years. Thus, based on this dispersion, all respondents fell into the Gen Y category, which according to Daniels (2007), comprises of persons born between 1977 and 1994.

As presented in Table 1, results for the preliminary testing show that for all measures, items loaded onto the appropriate factor with loadings ranging from 0.40 to 0.92 . Also, as shown in Table 1, using Cronbach's alpha, all constructs display high internal consistency with alpha scores ranging from 0.82 to 0.96 . Finally, as shown in Table 1, all measures have a variance explained that is greater than 0.5 , showing evidence of convergent validity (Fornell and Larcker, 1981) which means that the measures used in this study which theoretically should be related are actually related. In other words, they converge on one another. 
Analysis of the Materialism scale contains three factors with loadings ranging from 0.42 to 0.85. The total variance explained is 64 per cent with an alpha of 0.82 . Analysis of the FCI scale shows factor loadings between 0.84 and 0.92 . The total variance explained is 78 per cent and the scale shows a high internal consistency of 0.96. The RSI measure reveals loadings between 0.82 and 0.90 . The variance explained for the items in the scale is 73 per cent and alpha is highly reliable at 0.90. Analysis of the Market Mavenism scale reveals loadings between 0.82 and 0.92 . The variance explained for the items in the scale is 77 per cent and alpha is 0.94 . Finally, analysis of the PDI scale shows loadings between 0.78 and .88. The variance explained for the items in the scale is 69 per cent, with the scale possessing high internal consistency, with an alpha of 0.94 .

It must be noted that these quantitative techniques were not permissible for the OIS measures given the nature of the testing instrument. Accordingly, frequencies are reported for OIS, as shown in Table 2.

Take in table here (No.1)

\section{Take in table here (No.2)}

Following preliminary analysis, composite measures were calculated. A composite measure is "a method of combining several variables that measure the same concept into a single variable (composite measure)..." (Hair et al., 1998, p. 3). Calculating composite measures is widely accepted in consumer behaviour when testing for structural relationships. The means of the resulting composite measures range from 3.79 to 5.23 and the standard deviations range 
from 0.82 to 1.51 . To examine the study's scales for uniqueness, discriminate validity was then tested (Bagozzi et al., 1991). Using Gaski's (1984) recommendations, and as used by O'Cass (2004), discriminant validity is determined by assessing if the correlation between two composite constructs is greater than their respective reliability estimate. Inspection of correlations between all variables and their alpha scores was undertaken with discriminant validity evident for all measures. This shows that the constructs used in this study individually have more extracted variance, than variance shared between the constructs. In other words, they discriminate between one another (Fornell and Larcker, 1981; Miller, 2007).

\subsection{Main Study Results}

To test the relationships within the study's conceptual model, a variance based Structural Equation Modelling (SEM) technique named Partial Least Squares (PLS) was utilised. PLS is an increasingly popular form of SEM in the social sciences and is one of the most useful methods of analysis for models with multiple variables (Chin, 1998; Fornell and Bookstein, 1982). According to O'Cass (2001, p. 51), PLS is “a general technique for estimating path models involving latent constructs indirectly observed by multiple indicators". As succinctly explained by Miller (2007), PLS also considers all path coefficients simultaneously, thus permitting analysis of all paths at the one time - direct, indirect and spurious paths (Chin, 1998; Fornell and Bookstein, 1982). Recently PLS has been used for hypothesis testing in conceptual models in a number of similar studies within consumer behaviour (e.g. Miller, 2007; O’Cass, 2004).

When using PLS, Fornell and Cha (1994) recommend a systematic multi-index evaluation that includes the examination of $\mathrm{R}^{2}$, Average Variance Accounted for (AVA), Average 
Variance Explained (AVE), path coefficients (akin to regression weights) and bootstrap critical ratios (akin to t-statistics).

The results of the hypotheses of the study are presented in terms of the path coefficients between the exogenous and endogenous variables, AVA, $\mathrm{R}^{2}$ and critical ratios. As shown in Table 3, the AVA for the endogenous variables is 0.42 , while the individual $\mathrm{R}^{2}$ is greater than the recommended 0.10 for all of the predicted variables. The significance of the individual paths is calculated as a product from the path coefficient and the appropriate correlation coefficient, with 0.015 (1.5 per cent) as the recommended cut-off point (Bontis, 1998; Falk and Miller, 1992; Grace and O'Cass, 2004). All of the paths exceed this point. Finally, the bootstrap critical ratios are acceptable for all items (greater than 1.64 one-tail and 1.96 twotail).

\section{Take in Table here (No.3)}

As such, all paths $H 1, H 2, H 3, H 4, H 5$ and $H 6$ are supported, as shown in Figure I. The findings from this study suggest that materialism affects FCI significantly and that female Gen Y consumers are more involved in fashion clothing, while FCI in turn, leads to a greater propensity of RSI, market mavenism, PDI and OIS behaviours.

Take in Figure (No. I) 


\section{Discussion}

The present study developed an extended nomological network for FCI in the context of Australian Gen Y consumers. Overall, a number of interesting theoretical and practical implications arise from our findings. In terms of FCI drivers, this study found that materialistic values are a significant determinant of high FCI, and that women are more likely to display high FCI than men. The most interesting theoretical findings of this study however, relate to the outcomes of FCI and how these aspects of consumption thread together. In particular, a main effect of FCI in this study shows that RSI is a strong outcome variable. This provides empirical support for prior conceptualisations of the link between the personobject relationship and recreational shopping (Evrard and Aurier, 1996; Guiry et al. 1999). One explanation for this relationship may lie in how distinctly different the shopping activities are of consumers are who are highly involved in fashion clothing, from those who are not involved.

OIS was also consistent with high FCI where the more fashion clothing occupies a significant part of a consumer's life, the more time and effort will be spent with information sources to inform this area of interest. Given the visual and tactile nature of clothing, immersion with sources that provide relevant aesthetic cues may go some distance in explaining the popularity of fashion blogs and online stores as a relevant source of consumer information.

This study's results also show that both market maven characteristics and ongoing information search are significant outcomes of FCI. This means that highly involved fashion clothing consumers are not just interested in gathering marketplace information for themselves, but also engage in the sharing this information with others. While our finding contributes to the literature on market mavenism, this finding is perhaps of greatest interest 
and value to marketing practitioners. The challenge now is to develop and implement tools to foster these behaviours in highly involved consumers. According to the ELM, making information relevant to consumers is the best way to get them to use the central route to persuasion. Market mavens may certainly represent an avenue to increase relevance for non involved fashion clothing consumers.

As suggested by Browne and Kalenberg (1997), high involvement purchase decisions are thought to proceed through extended decision-making processes. Our findings support this claim and suggest that highly involved fashion consumers find making purchase decisions within fashion an involving process. A key question in attempting to better understand this aspect of consumer behaviour is to quantify the time and money such consumers invest within this market sector.

In addition to theoretical contributions made by this study, our findings also contribute to the collective understanding of Australian Gen Y consumers. Previous studies have ignored Australian Gen Y consumers, focusing instead on American (Bakewell and Mitchell, 2003; O'Donnell, 2006; Sullivan and Heitmeyer, 2008; Wolburg and Pokrywcyniski, 2001) and Asian Gen Y consumers (Arora, 2005; O'Cass and Choy, 2008; O'Cass and Lim, 2002). Gen Y has significant market potential in Australia and is predicted to be the most significant retail spending group by the year 2015 (Daniels, 2007). This is an important consideration when accounting for the current global economic climate and taking into account the aging Australian population.

For marketing practitioners, the results of this study also have interesting implications. This study is the first to empirically show RSI as an important consumer identity construct that is 
affected by consumer involvement. As consumers who identify themselves as recreational shoppers spend more time and money shopping, and shop across multiple shopping channels (e.g. brick-and-mortar, on-line stores, etc.) (Guiry et al., 2006), it is important to understand what influences RSI. Also, our finding that highly materialistic consumers are more likely to be involved in fashion clothing implies that tactics should be employed that nurture such values and that focus on notions of clothing being a part of the consumer self image and personal identity. For example, when targeting Australian Gen Y consumers, campaigns should focus on aspects of image management and portrayal.

Additionally, our study confirms that females have a greater orientation to involvement with fashion clothing. This finding is reflected today in Australian malls with many stores targeting females. For fashion marketers, it will continue to be a highly competitive area of business that requires careful planning to reach target consumers. Also, that FCI affects OIS, mavenism and PDI in fashion clothing shows the importance of understanding consumer involvement in retailing particularly when considering the increasing popularity of online stores based in Australia and abroad. By developing strategies and employing campaigns aimed to increase involvement in fashion clothing, companies may experience a significant flow-on effect in nurturing other positive market place behaviours, like market mavenism.

Whilst interesting findings have emerged from this study, they are bound by a number of limitations. In particular, the study used a non probability sample which means caution should be heeded when projecting the results of the study to the greater Australian Gen Y population. Also, this study used the broader term of fashion clothing, rather than using any particular fashion clothing brand names. On this issue, O'Cass $(2004,879)$ states "it is important to examine the relationship [of involvement] at the product class level before 
exploring if and how consumers transfer involvement from the product to specific brands with a product class". Overall, these limitations open new avenues for future research which could examine the study's conceptual model on a probability based sample and could also use real fashion brands to elicit responses. The study's conceptual model should be re-examined to determine external validity in future research. Finally, the role of RSI in consumer decision making in Australia and abroad, should be further examined, to determine if this new consumer research construct is globally significant to both marketing theory and practice. 


\section{References}

Arora, R. (2005). China's Gen Y bucks tradition: youngest Chinese reject Confucian work ethic, embrace west. The Gallup Poll Tuesday briefing, April 19. Retrieved January 12, 2009 from http://www.gallup.com/poll/15934/Chinas-Gen-Bucks-Tradition.aspx on $12 / 01 / 2009$

Assael, H., Pope, N., Brennan, L., \& Voges, K. (2007). Consumer behaviour. (Asia-Pacific ed.). Milton: Houghton Mufflin Wiley.

Australian Bureau of Statistics. (2009). Retail Turnover (\$ millions), By Industry Group (1)

Trend. Retrieved January 9, 2009 from

http://www.abs.gov.au/AUSSTATS/abs@.nsf/DetailsPage/8501.0Nov\%202008?OpenDo cument

Auty, S., \& Elliott, R. (1998). Fashion involvement, self-monitoring and the meaning of brands. The Journal of Product and Brand Management, 7(2), 109-123.

Bagozzi, R. P., Yi, Y., \& Phillips. L. W. (1991). Assessing construct validity in organisational research. Administrative Science Quarterly, 36(3), 421-458.

Bakewell, C., \& Mitchell, V. W. (2003). Generation Y female consumer decision-making styles. International Journal of Retail and Distribution Management, 31(2/3), 95-106.

Beatty, S. E. and Smith, S. M. (1987). Work and/or fun: Measuring hedonic and utilitarian shopping value. Journal of Consumer Research, 14, 83-95.

Belk, R.W (1988). Possessions and the Extended Self. Journal of Consumer Research, 15(2), 139-168

Belk, R. W. (1984). Three scales to measure constructs related to materialism: Reliability, validity, and relationships to measures of happiness. In T. Kinnear (Ed.), Advances in Consumer Research (pp. 291-297). Ann Arbor: Association for Consumer Research.

Belk, R. W. (1995). Materialism: Trait aspects of living in the material world. Journal of Consumer Research, 12(December), 265-280. 
Bellenger, D. N. \& Korgaonkar, P. K. (1980). Profiling the recreational shopper. Journal of Retailing, 56(3), 77-92.

Bettman, J. R. (1979). An information processing theory of consumer choice. Reading: Addison-Wesley.

Bloch, P.H. (1986). Product Enthusiasm: Many Questions, a Few Answers. In RJ Lutz (Ed.), Advances in Consumer Research, Provo, UT: Association for Consumer Research, Vol 13 (pp.539-543)

Bloch, P. H., Commuri, S., \& Arnold, T. J. (2009). Exploring the origins of enduring product involvement. Qualitative Market Research: An International Journal, 12(1), 49-69.

Bloch, P. H., Sherrell, D. L. and Ridgway, N. M. (1986). Consumer search: An extended framework. Journal of Consumer Research, 13, 119-126.

Bontis, N. (1998). Intellectual capital: An exploratory study that develops measures and models. Management decision, 36(2), 63-76.

Browne, B., \& Kaldenberg, D. (1997). Conceptualizing self-monitoring: Links to materialism and product involvement. Journal of Consumer Marketing, 14(1), 31-44.

Burroughs, J. E., \& Rindfleisch, A. (2002). Materialism and well-being: A conflicting values perspective. Journal of Consumer Research, 29, 348-370.

Chin, W. W. (1998). The partial least squares approach to structural equation modelling. In G. A. Marcoulides (Ed.), Modern methods for business research (pp. 295-336). New York: Lawrence Erlbaum Associates.

Chodorow, N. (1978). The reproduction of mothering. Stanford: Stanford University Press.

Clark, R. A. \& Goldsmith, R. E. (2005). Market mavens: Psychological influences. Psychology and Marketing, 22(4), 1-24.

Daniels, S. (2007). Gen Y considerations for the retail industry. Melbourne, Victoria: The Australian Centre for Retail Studies, Monash University.

Davis, F. (1994). Fashion, culture and identity. Chicago: University of Chicago Press.

Dittmar, H. (1992). The social psychology of material possessions: To have is to be. Hemel Hempstead: Harvester Wheatsheaf. 
D'Astous, A. (2000). Irritating aspects of the shopping environment. Journal of Business

Research, 49, 149-156.

Douglas, M., \& Isherwood, B. (1996). The world of goods: Towards an anthropology of consumption. New York: Routledge.

Eicher, J. B. \& Roach-Higgins, M. E. (1992). Definition and Classification of Dress: Implications for Analysis of Gender Roles. In Ruth Barnes \& Joanne B. Eicher (Eds.), Dress and Gender: Meaning and Making (pp. 13-28). Oxford: Berg.

Evrard, Y., \& Aurier, P. (1996). Identification and validation of the components of the person-object relationship. Journal of Business Research, 37, 127-134.

Falk, R. F., \& Miller, N. B. (1992). A primer for soft modelling. Akron: University of Akron Press.

Falk, P. \& Campbell, C. (1997). The shopping experience. London: Sage.

Fischer, E. and Gainer, B. (1991). I shop therefore I am: The role of shopping in the social construction of women's identities. Association for Consumer Research, 1, 350-357.

Feick, L. F. \& Price, L. L. (1987). The market maven: A diffuser of marketplace information. Journal of Marketing, 51, 83-97.

Flynn, L. R., \& Goldsmith, R. E. (1993). A casual model of consumer involvement: Replication and critique. Journal of Social Behavior and Personality, 86(6), 129-142.

Fornell, C., \& Cha, J. (1994). Partial least squares. In R. P. Bagozzi (Ed.), Advanced methods for marketing research (pp. 52-78). Cambridge: Basil Blackwell.

Fornell, C., \& Bookstein, F. L. (1982). Two structural equation models: LISREL and PLS applied to consumer exit-voice theory. Journal of Marketing Research, 19(4), 440-452.

Fornell, C., Larcker, D.F. (1981). Evaluating structural equation models with unobservable variables and measurement error. Journal of Marketing Research, 18, 39-50.

Fournier, S., \& Richins, M. L. (1991). Some theoretical and popular notions concerning materialism. Journal of Social Behaviour and Personality, 6(6), 403-414. 
Ganesan-Lim, C., Russell-Bennett, R., \& Dagger, T. (2008). The impact of service contact type and demographic characteristics on service quality perceptions. Journal of Services Marketing, 22(7), 550-561.

Gaski, J. F. (1984). The theory of power and conflict in channels of distribution. Journal of Marketing, 48(Summer), 9-29.

Gentry, J. W., Commuri, S., \& Jun, S. (2003). Review of literature on gender in the family. Academy of Marketing Science Review, 2003(1), 1-18.

Gilligan, C. (1987). Moral orientation and moral development. In E. Kittay \& D. Myers (Eds.), Women and moral theory (pp. 19-33). Tottowa: Rowan and Littlefield.

Goldsmith, R., Moore, M., \& Beaudoin, P. (1999). Fashion innovativeness and self-concept: a replication. The Journal of Product and Brand Management, 8(1), 7-15.

Goldsmith, R., Clark, R., \& Goldsmith, E. (2006). Extending the psychological profile of market mavenism. Journal of Consumer Behaviour, 5(Sept/Oct), 411-419.

Grace, D., \& O’Cass, A. (2004). Examining service experiences and post-consumption evaluations. Journal of Services Marketing, 18(6/7), 450-461.

Guiry, M., Mägi, A., \& Lutz, R. (2006). Defining and measuring recreational shopper identity. Journal of the Academy of Marketing Science, 34(1), 74-83.

Guiry, M., \& Lutz, R. J. (2000). Recreational shopper identity: Implications of recreational shopping and consumer self-definition. Working paper, University of Florida.

Haggard, L. M., \& Williams, D. R. (1992). Identity affirmation through leisure activities: Leisure symbols of the self. Journal of Leisure Research, 24(1), 1-18.

Hair, J.F., Anderson, R.E., Tatham, R.L., Black, W.C. (1998). Multivariate data analysis, 5th ed. Upper Saddle River: Prentice-Hall International. 
Hogg, M., Cox, A., \& Keeling, K. (2000). The impact of self-monitoring on image congruence and product/brand evaluation. European Journal of Marketing, 34(5/6), 641666.

Hulland, J. (1999). Use of Partial Least Squares (PLS) in strategic management research: A review of four recent studies. Strategic Management Journal, 20, 195-204.

Huntley, R. (2006). The world according to Y: Inside the new adult generation. Crows Nest: Allen and Unwin.

Josiassen, A. (2010). Young Australian consumers and the country of origin effect: Investigation of the moderating roles of product involvement and perceived product origin congruency. Australasian Marketing Journal, 18, 23-27

Kaiser, S. B. (1998). The social psychology of clothing $\left(2^{\text {nd }}\right.$ ed.). New York: Fairchild Publications.

Kasser, T. (2002). The high price of materialism. Cambridge, USA: MIT Press.

Kassarjian, H. H., \& Robertson, T. S. (1981). Social processes. In H. H. Kassarjian \& T. S. Robertson (Eds.), Perspectives in consumer behavior (pp. 317-328). Chicago: Scott, Foresman.

Kawamura, Y. (2005). Fashion-ology: An introduction to fashion studies. Oxford: Berg. Kim, H-S. (2005). Consumer profiles of apparel product involvement and values. Journal of Fashion Marketing and Management, 9(2), 207-220.

Konuş, U., Verhoef, P. C. \& Neslin, S. A. (2008). Multichannel shopper segments and their covariates. Journal of Retailing, 84(4), 398-413.

Krugman, H. E. (1965). The impact of television advertising: Learning without involvement. Public Opinion Quarterly, 29, 349-356.

Lunt, P. \& Livingstone, S. M. (1992). Mass consumption and personal identity. Philadelphia: University Press. 
Malhotra, N., Hall, J., Shaw, M., \& Oppenheim, P. (2006). Marketing research ( ${ }^{\text {rd }}$ ed.). Frenchs Forest: Pearson Education Australia.

McLuhan, M. (1964). Understanding media: The extension of man. New York: McGraw Hill.

Michaelidou, N., \& Dibb, S. (2006). Product involvement: An application in clothing. Journal of Consumer Behaviour, 5, 442-453.

Miller, K. W. (2007). Investigating the idiosyncratic nature of brand value. Australasian Marketing Journal, 15(2), 81-96.

Mittal, B. (1989). Measuring purchase-decision involvement. Psychology and Marketing, 6, 147-162.

Mittal, B., \& Lee, M-S. (1989). A causal model of consumer involvement. Journal of Economic Psychology, 10, 363-389.

Muehling, D.D., Laczniak, R.N., Andrews, C. (1993). Defining, operationalizing and using involvement in advertising research: A review. Journal of Current Issues and Research in Advertising, 15(1), 21-57.

O'Cass, A. (2000). An assessment of consumers' product, purchase decision, advertising and consumption involvement in fashion clothing. Journal of Economic Psychology, 21, 545576.

O'Cass, A. (2001). Consumer self-monitoring, materialism and involvement in fashion clothing. Australasian Marketing Journal, 9(1), 46-60.

O'Cass, A. (2004). Fashion clothing consumption: Antecedents and consequences of fashion clothing involvement. European Journal of Marketing, 38(7), 869-882.

O’Cass, A., \& Choy, E. (2008). Chinese generation Y consumers' involvement in fashion clothing. Journal of Product and Brand Management, 17(5), 341-352. 
O’Cass, A., \& Lim, K. (2002). Toward understanding the young consumer's brand associations and ethnocentrism in the Lion's Port. Psychology and Marketing, 19(9), 759775.

O’Donnell, J. (2006, November 10). Gen Y sits on top of consumer food chain. USA Today, p.3. Retrieved December 22, 2008, from http://gateway.library.qut.edu.au/login?url=http://search.ebscohost.com/login.aspx?direct $=$ true $\& \mathrm{db}=$ anh $\& A \mathrm{~N}=\mathrm{J} 0 \mathrm{E} 100394704306 \&$ site $=$ ehost-live

O’Shaughnessy, J., \& O’Shaughnessy, N. J. (2007). Reply to criticisms of marketing, the consumer society and hedonism. European Journal of Marketing, 41(1/2), 7-16.

Petty, R.E., Cacioppo, J.T. (1984). Effects of issue involvement on attitudes in an advertising context. In: Gorn, G.G., Goldberg, M.E. (Eds), Proceedings of the Division 23 Program, American Psychological Association, 75-79.

Petty, R.E., Cacioppo, J.T. (1984). The effects of involvement on responses to argument quantity and quality: Central and peripheral routes to persuasion. Journal of Personality and Social Psychology, 46, 69-81.

Prus, R., \& Dawson, L. (1991). Shop 'til you drop: Shopping as recreational and laborious activity. Canadian Journal of Sociology, 16, 145-164.

Richins, M. L. (1987). Media, materialism, and human happiness. In M. Wallendorf \& P. Anderson (Eds.), Advances in consumer research (pp. 352-356). Ann Arbor: Association for Consumer Research.

Richins, M. L. (1994). Special possessions and the expression of material values. Journal of Consumer Research, 21(December), 522-533.

Richins, M. L., \& Dawson, S. (1990). Measuring material uses: A preliminary report of scale development. In M. E. Goldberg, G. Gorn \& R. W. Pollay (Eds.), Advances in consumer research (pp. 169-175). Ann Arbor: Association for Consumer Research. 
Richins, M. L., \& Dawson, S. (1992). A consumer values orientation for materialism: Scale development and validation. Journal of Consumer Research, 19(December), 303-316.

Sassatelli, R. (2007). Consumer culture: History, theory and politics. Trowbridge: Sage Publications.

Schmidt, J. B., \& Spreng, R. A. (1996). A proposed model of external consumer information search. Journal of Academy of Marketing Science, 24(3), 246-256.

Shamir, B. (1992). Some correlates of leisure identity salience: Three exploratory studies. Journal of Leisure Research, 24(4), 301-323.

Smith, J. B., \& Bristor, J. M. (1994). Uncertainty orientation: Explaining differences in purchase involvement and external search. Psychology and Marketing, 11(6), 587-607.

Solomon, M., \& Schopler, J. (1982). Self-consciousness and clothing. Personality and Social Psychology Bulletin, 8, 508-514.

Solomon, M. R. (2004). Consumer behavior: Buying, having and being. (6 ${ }^{\text {th }}$ ed.). New Jersey: Pearson Prentice-Hall.

Stone, G. P. (1954). City and urban identification: Observations on the social psychology of city life. American Journal of Sociology, 60, 36-45.

Stokburger-Sauer, N.E., Hoyer, W.D. (2009). Consumer advisors revisited: What drives those with market mavenism and opinion leadership tendencies and why? Journal of Consumer Behaviour, 8 (2-3), 100-115.

Sullivan, P., \& Heitmeyer, J. (2008). Looking at Gen Y shopping preferences and intentions:

Exploring the role of experience and apparel involvement. International Journal of Consumer Studies, 32, 285-295.

Tigert, D., King, C., \& Ring, C. (1980). Fashion involvement: A cross-cultural analysis. Advances in Consumer Research, 3, 46-52.

Tigert, D., Ring C., \& King, C. (1976). Fashion involvement and buying behaviour: A methodological study. Advances in Consumer Research, 3, 46-52. 
Wang, J., \& Wallendorf, M. (2006). Materialism, status signalling and product satisfaction. Journal of the Academy of Marketing Science, 34(4), 494-505.

Westbrook, R. A. \& Black, W. C. (1985). A motivation-based shopper typology. Journal of Retailing, 61, 78-103.

Williams, T. E. \& Slama, M. E. (1995). Market maven's purchase decision evaluative criteria: Implications for brand and store promotion efforts. Journal of Consumer Marketing, $12(3), 4-21$.

Wolburg, J. M., \& Pokrywczynski, J. (2001). A psychographic analysis of Generation Y college students. Journal of Advertising Research, 41, 33-52.

Woodward, S. (2007). Why Women Wear What They Wear. Oxford: Berg. 
Figure I. Model of Fashion Clothing Involvement Drivers and Outcomes

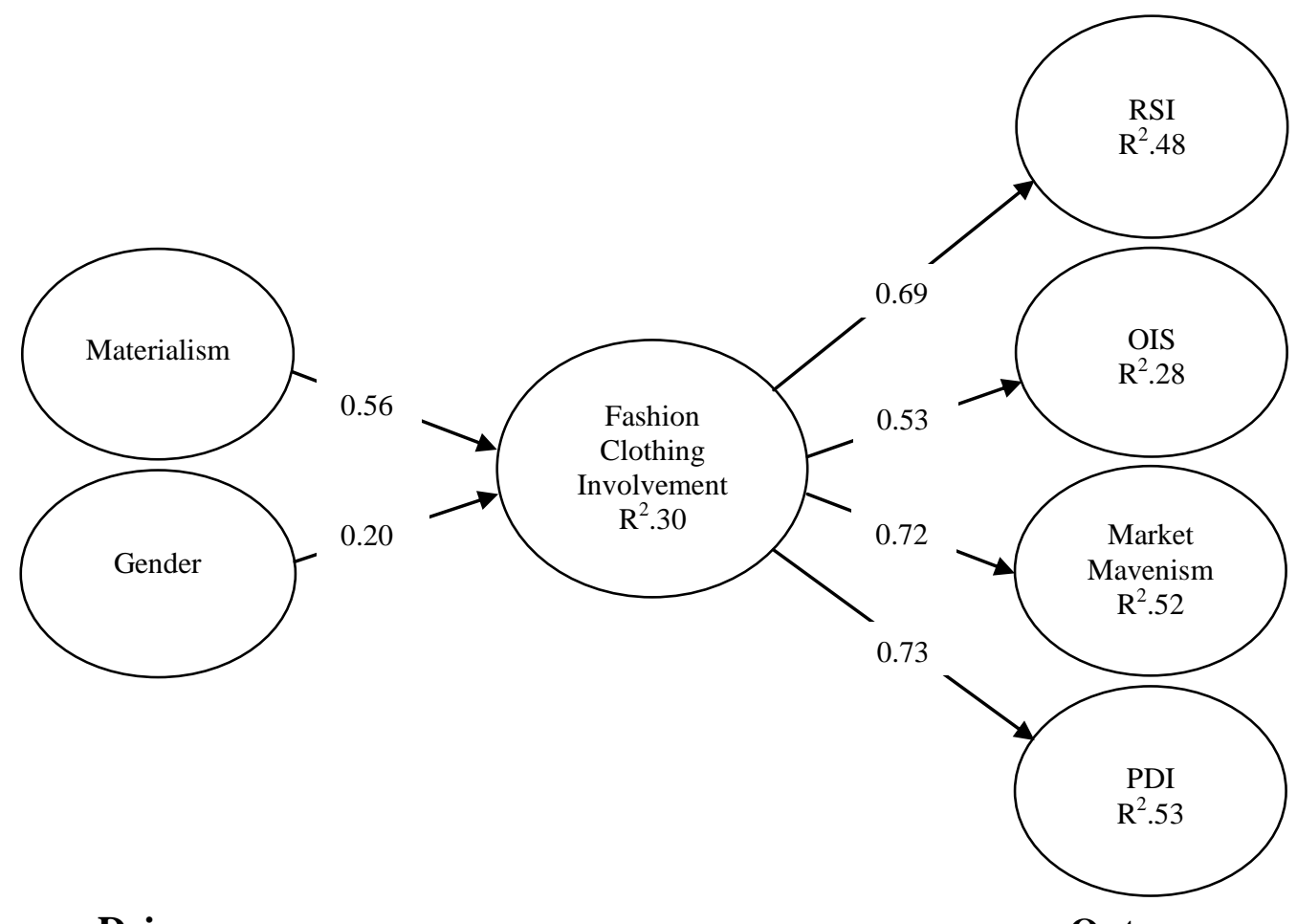

Drivers

Outcomes

Source: Developed for the Study 
Table 1. Preliminary outcomes

\begin{tabular}{|c|c|c|c|c|c|c|}
\hline Construct & Items & Mean & St. Dev & $\begin{array}{l}\text { Factor } \\
\text { loading }\end{array}$ & $\begin{array}{l}\text { Cronbach's } \\
\text { alpha }\end{array}$ & $\begin{array}{l}\text { Variance } \\
\text { explained }\end{array}$ \\
\hline Material. & Buy things need & 4.08 & 1.64 & .85 & & \\
\hline \multirow[t]{2}{*}{ Factor 1} & Life simple & 4.35 & 1.54 & .84 & & \\
\hline & Buying pleasure & 5.48 & 1.12 & .42 & & \\
\hline Material. & Admire people & 4.61 & 1.44 & .76 & & \\
\hline \multirow[t]{5}{*}{ Factor 2} & How I'm doing & 4.26 & 1.46 & .73 & & \\
\hline & Impress people & 4.40 & 1.50 & .78 & & \\
\hline & Attention to & 4.45 & 1.46 & .47 & & \\
\hline & Luxury & 4.86 & 1.32 & .60 & & \\
\hline & Nice things & 4.62 & 1.39 & .60 & & \\
\hline Material. & Enjoy life & 3.39 & 1.58 & .47 & & \\
\hline \multirow[t]{3}{*}{ Factor 3} & Life better & 4.58 & 1.59 & .82 & & \\
\hline & Happier if buy & 4.87 & 1.59 & .82 & & \\
\hline & I wish afford & 5.89 & 1.27 & .68 & .82 & $56 \%$ \\
\hline \multirow[t]{8}{*}{$F C I$} & Means a lot & 4.69 & 1.59 & .84 & & \\
\hline & Significant part & 4.37 & 1.66 & .92 & & \\
\hline & Central part & 3.47 & 1.74 & .84 & & \\
\hline & Think about & 3.87 & 1.86 & .90 & & \\
\hline & Interested in & 4.88 & 1.10 & .87 & & \\
\hline & Completely involved & 3.41 & 1.83 & .86 & & \\
\hline & Important to me & 4.38 & 1.68 & .90 & & \\
\hline & Relevant product & 4.31 & 1.71 & .90 & .96 & $78 \%$ \\
\hline \multirow[t]{5}{*}{$R S I$} & Important for self-identity & 4.20 & 1.52 & .86 & & \\
\hline & Contributes to self-esteem & 4.52 & 1.54 & .85 & & \\
\hline & Part would be missing & 3.43 & 1.78 & .83 & & \\
\hline & Affirms values & 3.42 & 1.50 & .90 & & \\
\hline & Realise aspirations & 3.36 & 1.66 & .82 & .90 & $73 \%$ \\
\hline
\end{tabular}




\begin{tabular}{|c|c|c|c|c|c|c|}
\hline Market & Brands & 4.13 & 1.73 & .85 & & \\
\hline \multirow[t]{5}{*}{ maven } & Helping people & 4.05 & 1.68 & .88 & & \\
\hline & Places to shop & 4.09 & 1.74 & .92 & & \\
\hline & Where to go & 4.26 & 1.65 & .87 & & \\
\hline & Good source & 3.86 & 1.64 & .92 & & \\
\hline & Know about & 3.94 & 1.66 & .82 & .94 & $77 \%$ \\
\hline \multirow[t]{8}{*}{$P D I$} & Is significant & 4.10 & 1.56 & .81 & & \\
\hline & Completely involved & 4.01 & 1.58 & .82 & & \\
\hline & Think a lot & 4.71 & 1.40 & .84 & & \\
\hline & Great value & 4.81 & 1.38 & .85 & & \\
\hline & Very important & 4.58 & 1.44 & .88 & & \\
\hline & A lot of thought & 4.55 & 1.45 & .78 & & \\
\hline & Like being involved & 4.70 & 1.50 & .80 & & \\
\hline & Is important & 4.37 & 1.50 & .85 & .94 & $69 \%$ \\
\hline
\end{tabular}


Table 2. Frequency scores for OIS

Source

Frequency

Internet

40

Fashion magazines

36

Clothing stores

56

Friends (talking to and observing)

20

Catalogues online

4

Catalogues offline

2

Peers

3

Television shows

1

Observation

1

Television advertisements

1

Cumulative per cent of top four info sources

$91.6 \%$ 
Table 3. Hypothesis results via PLS

\begin{tabular}{ccccccr}
\hline $\begin{array}{c}\text { Predicted } \\
\text { variables }\end{array}$ & $\begin{array}{l}\text { Predictor } \\
\text { variables }\end{array}$ & Hypothesis & Path & $\begin{array}{c}\text { Variance } \\
\text { due to path }\end{array}$ & R2 & $\begin{array}{r}\text { Critical } \\
\text { ratio }\end{array}$ \\
\hline Involve. & Mat. & $H 1$ & 0.53 & 0.268 & 0.30 & 9.26 \\
& Gender & $H 2$ & 0.20 & 0.039 & & 4.04 \\
RSI & Involve. & $H 3$ & 0.69 & & 0.48 & 13.58 \\
MM & Involve. & $H 4$ & 0.72 & & 0.52 & 17.26 \\
PDI & Involve. & $H 5$ & 0.73 & & 0.53 & 15.86 \\
OIS & Involve. & $H 6$ & 0.53 & & 0.28 & 8.76 \\
AVA & & & & & $\mathbf{0 . 4 2}$ &
\end{tabular}

